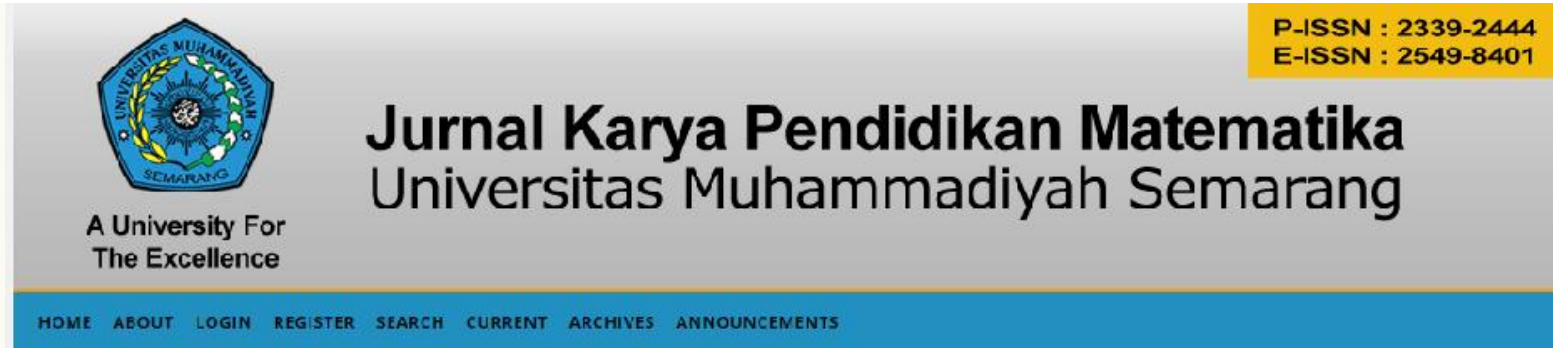

\title{
PENGEMBANGAN MEDIA PEMBELAJARAN BERBASIS ANDROID PADA MATAKULIAH STATISTIKA PENDIDIKAN
}

\author{
Oleh: Eko Andy Purnomo ${ }^{1}$, Bambang Dalyono ${ }^{2}$, Sri Handayani ${ }^{3}$ \\ 'ekoandy@unimus.ac.id, ${ }^{2}$ bambangd@ecampus.ut.ac.id, ${ }^{3}$ handayani@ecampus.ut.ac.id \\ ${ }^{1}$ FMIPA Universitas Muhammadiyah Semarang \\ ${ }^{2,3}$ FKIP UPBJJ UT Semarang
}

\begin{tabular}{ll}
\hline \multicolumn{2}{l}{ Article history } \\
\hline Submission & $: 19 / 8 / 2018$ \\
Revised & $:-$ \\
Accepted & $: 22 / 8 / 2018$
\end{tabular}

Keyword:

4D development, android, learning media, statistics education subject

\begin{abstract}
The curriculum and technology development hand in hand very rapidly, so it takes a concept and mechanism of ICT-based teaching and learning. The transformation process of conventional education into digital form, both in its content and its system. The progress of this technology should be utilized by the students as a provision in the classroom learning. Students are required to innovate and apply ICT in learning. Based on these things required a design and supplement learning materials so students can carry out in accordance with the demands. The one of innovation form is android-based learning media on $n$ statistical education subject. The stages of this android system using pretest, practice working on the matter, as well as a posttest. In addition, the whole tutorial material such as SAT, RAT, concept maps and materials could be obtained by students through media-based android. The purpose of this research is to 1). know the process of developing android-based learning media is valid, 2). know the response of the students towards the implementation of the androidbased learning media. The subject of this research was students of UTUPBJJ Semarang pokjar Kendal. The development of the design and supplement learning materials used the 4-D model of Thiagarajan, Semmel Semmel and IE (define, design, develop, and disseminate). The method of data collection used interviews, observation, and question form. Based on the stages of the learning media development can be concluded 1). the android-based learning media development on educational statistics subject. The validity got 4.22 and included within the category of very valid. 2).The students 'responses on the media-based learning android on education statistics subject had good responses. The students' responses categories were very good 3.40.
\end{abstract}

\section{Pendahuluan}

Perkembangan kurikulum dan teknologi beriringan sangat pesat, sehingga dibutuhkan suatu konsep dan mekanisme belajar mengajar berbasis TIK. Perkembangan teknologi mengharuskan adanya inovasi dan transformasi dalam pembelajaran (Hussin dkk, 2015). Proses transformasi pendidikan konvensional ke bentuk digital, baik secara isi 
dan sistemnya. Penggunaan TIK dalam pendidikan begitu banyak jumlahnya, sehingga dapat mengarah pada pengalaman belajar yang kreatif dan menyenangkan serta meningkatkan daya saing dan keunggulan kompetitif. Pengalaman belajar tidak hanya di ruang kelas, tetapi juga transformasi model pendidikan, contohnya seperti model jarak jauh ke model $e$ learning atau blended learning yang menawarkan pilihan baru dalam penyampaian. Renstra Universitas Terbuka didalamnya termaktub bahwa dosen harus mampu menciptakan pembelajaran yang menarik dengan berbasis ICT.

Kemajuan dalam TIK ini harus bisa dimanfaatkan oleh mahasiswa UT sebagai bekal dalam pembelajaran di kelas. Mahasiswa dituntut harus bisa berinovasi dan mengaplikasikan TIK dalam pembelajaran. Salah satu bekal mahasiswa di UT untuk berinovasi dan memanfaatkan TIK dalam pembelajaran adalah pada matakuliah statistika pendidikan. Melalui matakuliah tersebut mahasiswa diharapkan dapat menerapkan statistika dalam permasalahan sehari-hari. Berdasarkan observasi pada mahasiswa UT pada 2017.1 dan 2017.2 disimpulkan bahwa 1). hasil belajar mahasiswa pada matakuliah statistika pendidikan kurang, 2). banyak mahasiswa hanya bisa menyerap teori, tetapi tidak mengaplikasikan dalam pembelajaran, 3). Belum adanya android materi matakuliah statistika pendidikan yang secara holistik membantu belajar mandiri mahasiswa, 5). Belum ada penerapan blended learning berbasis project based learning.

Berdasarkan permasalah di atas diperlukan suatu media pembelajaran berbasis android yang dapat meningkatkan keaktifan dan motivasi mahasiswa. Pemanfaatan teknologi ini telah dilakukan dibeberapa penelitian dan telah terbukti hasilnya. Pembelajaran berbasis teknologi dapat meningkatan pemahaman karakter dan kemampuan analisis siswa (Sukestiyarno, 2008), membuat guru dan siswa mudah dalam memahami materi matematika (Sukestiyarno, 2012) dan lebih tertarik dan antusias dalam mengikuti pelajaran dan lebih efektif waktunya karena dikemas secara cetak dan online (Lusi dan Paridjo, 2014).

Pengembangan media pembelajaran menggunakan model pengembangan sistem Thiagarajan, Semmel dan Semmel (1974) dikenal dengan model 4-D, model ini terdiri dari 4 tahap yaitu: define (pendefinisian), design (perancangan), develop (pengembangan), dan disseminate (penyebaran). Tahap 1 : Pendefinisian (Define) Tujuan tahap ini adalah menetapkan dan mendefinisikan syarat-syarat pembelajaran. Langkah-langkahnya : analisis awal-akhir (front-end analysis), analisis siswa (learner analysis), analisis tugas, analisis konsep, tujuan pengajaran khusus. Tahap 2 : Perancangan (Design) Tujuan tahap ini adalah untuk menyiapkan prototipe perangkat pembelajaran. Tahap 3 : Pengembangan (Develop) Tujuan tahap ini adalah untuk memodifikasi prototipe perangkat pembelajaran. Tahap 4 : Penyebaran (Disseminate) Tahap akhir dari pengembangan perangkat ini adalah penyebaran yang terdiri dari 3 tahap yaitu pengujian validasi, pengemasan dan difusi dan adopsi. Model pengembangan yang digunakan untuk mengembangkan bahan ajar dalam penelitian ini adalah modifikasi dari model Thiagarajan, Semmel, dan Semmel. Model 4-D dipilih karena sistematis dan cocok untuk mengembangkan perangkat pembelajaran, namun dalam penelitian ini peneliti melakukan modifikasi terhadap model 4-D.

\section{Metode Penelitian}

Subjek penelitian ini adalah mahasiswa UT Semarang 2018.1 yang mengambil matakuliah Statistika Pendidikan. Pelaksanaannya penelitian mengambil Pokjar di kecamatan Boja kabupaten Kendal. Penelitian ini adalah research and development yaitu pengembangan media pembelajaran pada matakuliah Statistika Pendidikan. Bahan ajar yang dikembangkan meliputi media pembelajaran berbasis sndroid, buku ajar dan KIT tutorial pada matakuliah Statistika Pendidikan. Model pengembangan yang digunakan adalah model 4-D dari Thiagarajan, Semmel dan Semmel yang dimodifikasi.

\section{Hasil Penelitian dan Pembahasan}

Model pengembangan Thiagarajan, Semmel dan Semmel (1974) dikenal dengan model 4-D, model ini terdiri dari 4 tahap yaitu: define (pendefinisian), design (perancangan), develop (pengembangan), dan disseminate (penyebaran).

Tahap Pendefinisian ini menganalisis terkait karakterristik, mahasiswa UT, pelaksanaan tutorial, dan karakteristik materi Statistika Pendidikan. Melalui kombinasi ketiga 
materi tersebut nantinya akan membuat materi dalam media pembelajaran semakin lengkap. Karakteristik mahasiswa UT sebagian besar sudah mengajar di SD sehingga materi terkait matematika SD bisa langsung didesain untuk menjadi tugas. Tutorial tatap muka mahasiswa UT berlangsung selama 8 kali. Berdasarkan itu maka desain media pembelajaran ini sebanyak 8 tahapan. Masing - masaing tahapan disesuaikan dengan karakteristik pertemuan seperti pada pertemuan 3, 5 dan 7 terdapat tugas tutorial. Maka pada tahap tersebut didesain ada tugas tutorial yang harus diselesaikan di kelas dengan waktu 60 menit. Kemudian pada tahap 1 terdapat pre test dan tahap 8 ada pos test. Pada pre test dan post tes mahasiswa dapat langsung mengetahui hasil nilai yang didapatkan. Setiap tahapan pada media ini juga ada peta konsep dan rangkuman materi.

Berdasarkan hasil observasi dan wawancara banyak mahasiswa mengalami kesulitan dalam mempelajari materi Statistika Pendidikan karena 1). Ada beberapa materi matakuliah Statistika Pendidikan yang belum pernah didapatkan oleh mahasiswa yaitu Pengujian hipotesis penelitian (uji z, uji t, uji F, uji $\chi^{2}$ ), analisis regresi dan korelasi dan aplikasinya. 2). Dalam pengujian terdapat banyak pengujian diantaranya uji z, uji t, uji F, dan uji $\chi^{2}$ beserta tabel dan kurvanya masingmasing hal ini membuat mahasiswa belum bisa membedakan kapan harus menggunakan pengujian dalam penyelesaian soal. 3). Terdapat banyak rumus seperti mencari nilai rata-rata, mean, median, modus, kuartil, desil dan persentil serta terdapat jeni data tunggal dan kelompok. 4). Materi Statistika Pendidikan mempunyai tingkat kesulitan yang sangat tinggi sehingga diperlukan analisis yang tinggi dan pemahaman yang cukup lama. Berdasarkan analisis ketiga karakteristik tersebut maka dibuat tujuan dan indicator matakuliah Statistika Pendidikan.

Tahap selanjutnya adalah mendesain media pembelajaran berbasis android. Media pembelajaran android pada matakuliah Statistika Pendidikan didesain sesuai karakteristik materi Statistika Pendidikan, karakteristik mahasiswa UT dan pertemuan tutorial. Pada tampilan menu materi nanti didesain sesuai dengan karakteristik materi pada matakuliah Statistika Pendidikan. Data base dapat menampilkan mahasiswa yang sudah login/ masuk dalam sistem media pembelajaran.
Data base juga bisa menampilkan aktifitas mahasiswa dalam mempelajari materi yang ada. Kemampuan yang lainnya juga bisa melihat seberapa lama mahasiswa mempelajari materi tersebut dan kapan waktu mempelajarinya. Berdasarkan hal tersebut bisa digunakan untuk menganalisis aktifitas mahasiswa. Pengelompokan materi juga didasarkan karakteristik pertemuan tutorial tatap muka Tutorial tatap muka mahasiswa UT berlangsung selama 8 kali. Berdasarkan itu maka desain media pembelajaran ini sebanyak 8 tahapan. Masing - masaing tahapan disesuaikan dengan karakteristik pertemuan seperti pada pertemuan 3, 5 dan 7 terdapat tugas tutorial. Setiap tahapan pada media ini juga ada peta konsep dan rangkuman materi. Media pembelajaran ini juga berisi contoh soal dan latihan soal yang dapat digunakan mahasiswa untuk mengasah kemampuan

Pada tahap pengembangan ini yaitu validasi ahli. Pada tahap validasi ahli menggunakan 3 ahli yaitu ahli evaluasi, Statistika dan media pembelajaran. hasil validasi pakar evaluasi dengan nilai 4,2 validasi pakar Statistika dengan nilai 4,15 dan validasi pakar media pembelajaran 4,3. Rata-rata validasi ahli sebesar 4,22 yang termasuk pada kategori sangat valid. Hasil validasi ahli dapat dilihat pada tabel di bawah ini.

Tabel 1. Hasil validasi ahli terhadap media pembelajaran

\begin{tabular}{|c|c|c|c|}
\hline & Validator & $\begin{array}{c}\text { Keahlian/ } \\
\text { Kepakaran }\end{array}$ & $\begin{array}{c}\text { Rata-rata } \\
\text { Hasil } \\
\text { Validasi }\end{array}$ \\
\hline 1 & Validator 1 & Evaluasi & 4.2 \\
\hline 2 & Validator 2 & Statistika & 4.15 \\
\hline 3 & Validator 3 & $\begin{array}{c}\text { Media } \\
\text { Pembelajaran }\end{array}$ & 4.3 \\
\hline \multicolumn{3}{|c|}{ Rata-rata } & 4.22 \\
\hline \multicolumn{3}{|c|}{ Kategori } & Sangat Valid \\
\hline
\end{tabular}

Tahap keempat adalah pengembangan media pembelajaran. Pada tahap ini media pembelajaran diterapkan pada mahasiswa pokjar Boja pada matakuliah Statistika Pendidikan. Penerapan media ini dilaksanakan sebanyak 8 kali pertemuan. Setelah melakukan pembelajaran mahasiswa diberi angket 
respon mahasiswa terhadap media pembelajaran. angket respon menggunakan 4 indikator yaitu Fungsi Media Pembelajaran, Manfaat Media Pembelajaran, Aktivitas peserta didik, Efektifitas Media Pembelajaran. Hasil respon mahasiswa dapat dilihat pada gambar dibawah ini

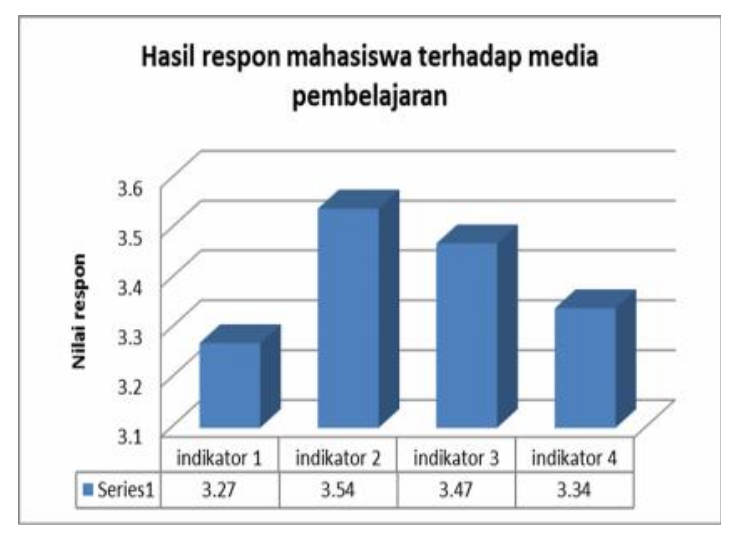

Gambar 1. Respon mahasiswa terhadap media

Berdasarkan gambar 1 dapat dilihat bahwa untuk indikator 1 nilai 3,27 termasuk pada kategori sangat baik. Indikator 2 nilai persentase 3,54 , indicator 3 dengan nilai 3,47 dan indikator 4 sebesar 3,34. Berdasarkan data semua indikator termasuk pada kategori sangat baik. Berdasarkan respon mahasiswa melalui 4 indikator dapat disimpulkan media pembelajaran direspon sangat baik oleh mahasiswa. Media pembelajaran dapat meningkatkan aktifitas dan efektivitas pembelajaran

\section{Simpulan dan Saran}

Berdasarkan tahapan pengembangan media pembelajaran dapat disimpulkan bahwa dihasilkan media pembelajaran berbasis android pada matakuliah Statistika Pendidikan yang valid. Hasil validasi ahli dengan rata-rata 4,22 dengan kategori sangat baik. Respon mahasiswa terhadap media pembelajaran sangat baik dengan nilai rata-rata sebesar 3,4 .

\section{Daftar Pustaka}

Hussin dkk. 2015. Kajian Model Blended Learning Dalam Jurnal Terpilih: Satu Analisa Kandungan. Jurnal Kurikulum \& Pengajaran Asia Pasifik. Vol. 3 nomor 1 januari 2015

Lusi dan Paridjo. 2014. Pengembangan Media Matiklopedia (Matematika Ensiklopedia) berbasis Character Building di Sekolah Dasar. Jurnal Aksioma. Vol 5,No. 2.

Sukestiyarno dkk. 2008. The effective learning of mathematics: central tendency using integrated and discovery strategy based on technology application. Jurnal IJERN. Vol 10, No. 2. . 2012. Developing heroics cooperative learning model based on technology and SWOT analysis orientation on mathematics at SMA. Jurnal IJERN. Vol 11, No. 2.

Thiagarajan, S., D. S. Semmel, and M. I. Semmel. 1974. Instructional Development for Training Teachers of Exceptional Children, A Source Book. Blomington: Indiana University 